\title{
Neuronavigation in Cranioorbital Neurosurgery - Do We Really Need It?
}

\author{
Kranyoorbital Nöroşirürjide Nöronavigasyon - Gerçekten İbtiyacımı \\ $\operatorname{Var} M i$ ?
}

\author{
Yavor ENCHEV, Christo TZEKOV, Dilyan FERDINANDOV, Assen CEKOV, Toma SPIRIEV \\ Medical University - Sofia, Department of Neurosurgery, Sofia, Bulgaria
}

Correspondence address: Yavor ENCHEV / E-mail: dr.y.enchev@gmail.com

\begin{abstract}
AIM: The value of neuronavigation in cranioorbital neurosurgery is controversial and relatively unstudied. The aim of this study was to evaluate the application, the usefulness and the reliability of neuronavigation in the neurosurgical treatment of orbital tumours.

MATERIAL and METHODS: A frameless armless infrared-based neuronavigation system was applied in the microsurgical removal of 7 orbital tumors. Image guidance was CT-based in 3 cases, MRI-based in another 3 cases and based on image fusion between CT and MRI image sets in one patient. The extradural fronto-orbital approach was performed in 3 cases, lateral orbitotomy in 2 cases, trans-supraciliar approach in 1 case and inferomedial orbitotomy in 1 case.

RESULTS: The surgical procedures were successful in all cases. The procedure-related morbidity and mortality rate in the series was zero. The registration accuracy of the neuronavigation ranged between 1.0 and $1.7 \mathrm{~mm}$, with an average of $1.3 \mathrm{~mm}$. Neuronavigated image guidance was evaluated as useful in all patients. Total tumour removal was achieved in 5 patients and partial tumour excision in 1 case. One patient was only biopsied.
\end{abstract}

CONCLUSION: Neuronavigation is not a substitute for surgical knowledge and experience, but it is a valuable complement with significant intraoperative potential in cranioorbital surgery.

KEYWORDS: Orbital tumours, Neurosurgery, Image-guided neurosurgery, Neuronavigation

öz

AMAÇ: Kranyoorbital nöroşirürjide nöronavigasyonun değeri tartışmalıdır ve nispeten az çalışılmıştır. Bu çalışmanın amacı orbital tümörlerin nöroşirürjikal tedavisinde nöronavigasyonun uygulamasını, yararlılı̆ını ve güvenilirliğini değerlendirmektir.

YÖNTEM ve GEREÇ: Çerçevesiz kolsuz infraruz temelli bir nöronavigasyon cihazı 7 orbita tümörünün mikrocerrahisinde kullanıldı. Image guidance 3 vakada BT temelli, 3 vakada MRG-temelli ve bir vakada da BT ve MRG görüntülerinin birleştirilmesiyle idi. 3 vakada ekstradural fronto-orbital yaklaşım, 2 vakada lateral orbitotomi, 1 vakada trans-suprasilier yaklaşım ve 1 vakada inferomedial orbitotomi uygulandı.

BULGULAR: Cerrahi işlemler bütün vakalarda başarılı oldu. Seride işlemle ilgili morbidite ve mortalite sıfırdı. Nöronavigasyonun rejistrasyon keskinliği 1.0 ve $1.7 \mathrm{~mm}$ arasında değişiyordu ve ortalaması $1.3 \mathrm{~mm}$ idi. Nöronavigasyon bütün hastalarda yararlı olarak değerlendirildi. 5 hastada tümör total çıkarıldı ve 1 hastada kısmi çıkarıldı. Bir hastaya sadece biyopsi yapıldı.

SONUÇ: Nöronavigasyon cerrahi bigi ve tecrübenin yerini tutacak bir şey değildir ancak kranyoorbital cerrahide belirgin intraoperatif potansiyeli ile değerli bir tamamlayıcıdır.

ANAHTAR SÖZCÜKLER: Orbital tümörler, Nöroşirürji, Image-guided nöroşirürji, Nöronavigasyon

\section{INTRODUCTION}

In less than three decades, neuronavigation became an essential part of the neurosurgical armamentarium with potential benefits in each neurosurgical procedure (4-10, 13, 15-17). However, the application of neuronavigation in cranioorbital neurosurgery has been rarely reported $(1-3,11$, $12,14,18,19)$. The complex anatomy of the orbital region, with the pronounced vulnerability of its neurovascular structures, requires special precautions. Neuronavigation, as a high-tech device for intraoperative safety, represents a valuable option for the confined orbital space.

The purpose of this study was to evaluate and analyze the application, the usefulness and the reliability of neuronavigation in the neurosurgical treatment of orbital lesions.

\section{MATERIAL and METHODS}

The study included 7 patients (two male and five female) with orbital tumours treated neurosurgically with 
neuronavigational assistance (Table I). The patients' age ranged from 40 to 63 years (average age 55.7 years). All patients underwent clinical, neurological and thorough ophthalmological examinations including visual acuity testing, visual field perimetry, fundoscopy, evaluation of ocular motor functions and the degree of proptosis by Hertel exophthalmometry. The cranial imaging examination was detailed enough to meet the requirements of neuronavigation. Two lesions were isolated in the extraconal space (one sarcoid granuloma and one abscess (patients no. 1 and 7) and four in the intraconal space (four cavernomas- patients no. 3, 4, 5 and 6) (Table I). Both the intra- and extraconal spaces were engaged in one patient with orbital pseudotumour (patient no. 2). Bony involvement as well as lacrimal gland infiltration was not found in the series.

A frameless armless infrared-based neuronavigation system (VectorVision2, BrainLAB, Heimstetten, Germany) was applied in the microsurgical removal of the orbital tumours. Image guidance was CT-based in 3 cases, MRI-based in another 3 cases and based on image fusion between CT and MRI image sets in one patient. The target lesions were outlined preoperatively on the neuronavigational image sets and the most appropriate surgical approaches were selected and simulated. The patients' heads were fixed in a Mayfieldheadrest. The registration process in the series was fiducialless and performed by a laser device (Z-touch ${ }^{\circledR}$, BrainLAB, Heimstetten, Germany) aiming at a registration accuracy of less than $3 \mathrm{~mm}$. Intraoperatively, the neuronavigation accuracy was checked periodically by pointing facial bony landmarks. The extradural fronto-orbital approach was performed in 3 cases, lateral orbitotomy in 2 cases, trans-supraciliar approach in 1 case and inferomedial orbitotomy- in 1 case (Table I). The minimal follow-up in the series was 3 months.

\section{RESULTS}

The signs and symptoms, of the patients in the series, included proptosis in five cases, decreased visual acuity in four cases, impaired ocular motility in three cases, and pain and conjunctival redness in two cases each (Table II).

The surgical procedures were successful in all cases. The procedure-related morbidity and mortality rate in the series was 0 . The registration accuracy of the neuronavigation ranged between 1.0 and $1.7 \mathrm{~mm}$, with an average of $1.3 \mathrm{~mm}$. The intraoperative neuronavigation accuracy, checked by pointing typical anatomical bony landmarks, was estimated as consistently high. Neuronavigated image guidance was evaluated as useful in all patients. Total tumor removal was achieved in 5 patients (patients no. 3, 4, 5, 6 and 7). Partial tumor excision was performed in 1 case (patient no. 1) and biopsy in 1 patient (patient no. 2). The histological examination revealed four patients with cavernomas (Figure $1 A, B)$, one case with sarcoid granuloma (Figure 2), one with orbital pseudotumour and one with abscess (Figure 3 ).

The ophthalmological outcome was beneficial for all patients in the series as proptosis resolved completely in $5 / 5$ patients, visual acuity increased in 3/4 patients (remained unchanged in $1 / 4$ ), ocular motility was restored in $2 / 3$ patients (remained unchanged in 1/3), orbital pain disappeared in $2 / 2$ cases and conjunctival redness was affected in 2/2 cases.

\section{DISCUSSION}

\section{Neuronavigation in Cranial Neurosurgery}

Neuronavigation is a high-tech device with a proven value in contemporary neurosurgery. Intraoperatively, neuronavigation provides neurosurgeons with meticulous coregistration between the processed virtual image space and the real anatomical space. In this way the frameless stereotaxy allows precise localization, safe dissection guidance and exact orientation for the extent of tumour resection $(4,7,8,10,17)$.

Nowadays, neuronavigation, although widely used in cranial neurosurgery, is also incidentally reported in cranioorbital surgery.

\section{Neuronavigation in Cranioorbital Surgery}

Cranioorbital surgery has some particular features due to the specific anatomy of the region.

\section{Anatomical features of the orbit and its content}

The orbital space is significantly smaller than the intracranial space. The orbital bony walls are the reason for the predominant anterior displacement (proptosis) of the orbital content in case of orbital tumour. The orbital neurovascular and ocular structures, being indispensable for visual function, are extremely delicate, vulnerable and irreparable. The extraconal orbital space is actually in the intimate vicinity of the bony orbital walls and therefore extraconal tumours could be regarded as skull base tumours with a practically non-existing brain shift phenomenon (11). The situation is similar to intraconal tumours, which are confined to the tiny intraconal space without possibility of significant dislocation (brain shift) (11).

\section{Literature review}

There are currently only 9 papers in the literature, including the present one, that describe the application of neuronavigation in the field of cranioorbital surgery to the best of our knowledge (Table III). The first study of the subject was published by ophthalmologists (2) in 2001, 15 years after the introduction of neuronavigation in cranial neurosurgery by David Roberts in 1986 (17). Of the aforementioned papers, all but one (11) were written by an ophthalmologist and were published in ophthalmological journals.

The total number of the patients in the analyzed series is quite limited at only 59, including the 7 cases presented by the authors.

\section{Type of neuronavigation device}

In our series, we used an armless frameless stereotactic system, based on passive reflection of infrared lights (10). Including our study, an optical neuronavigation device has been used 

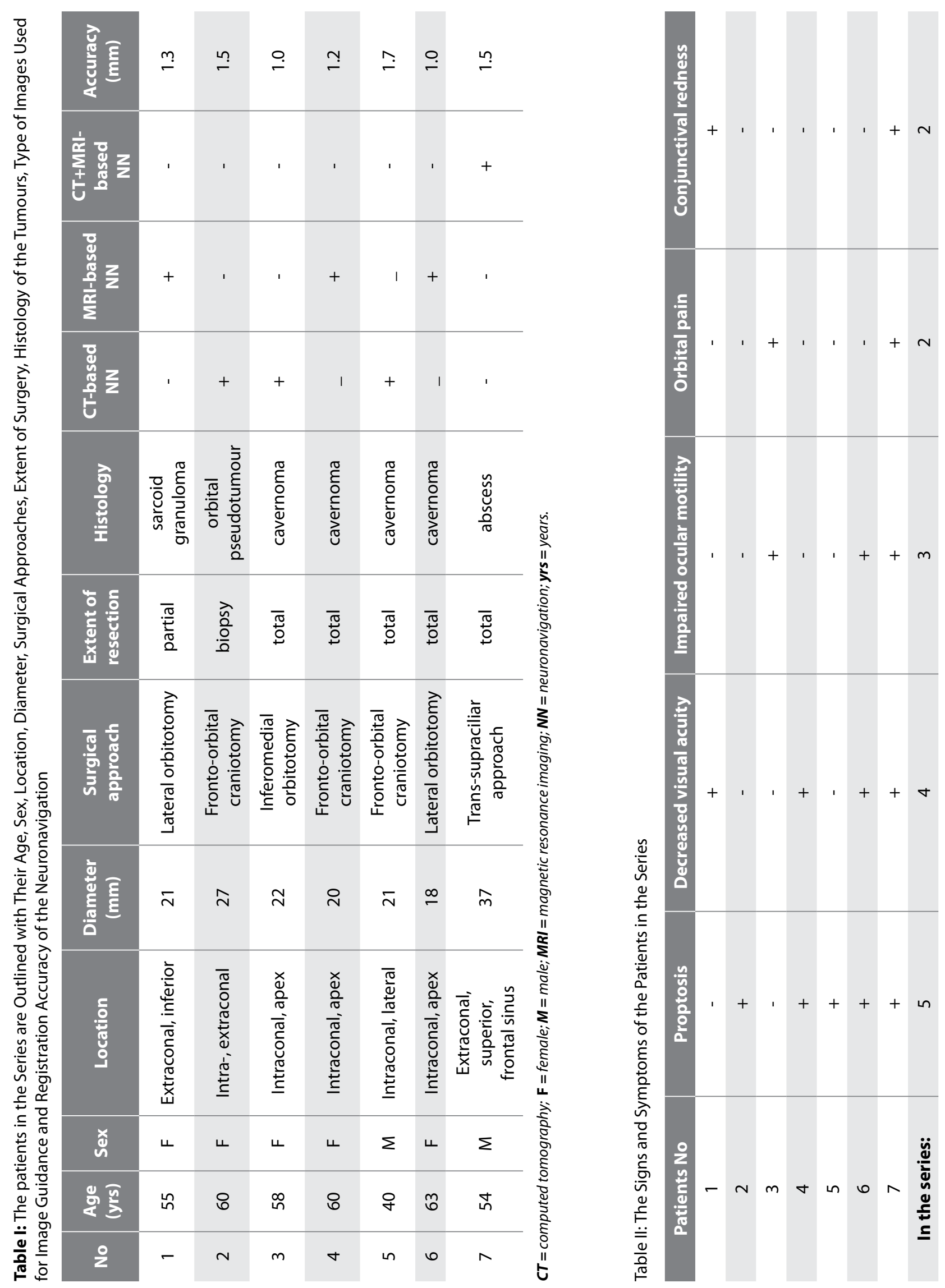

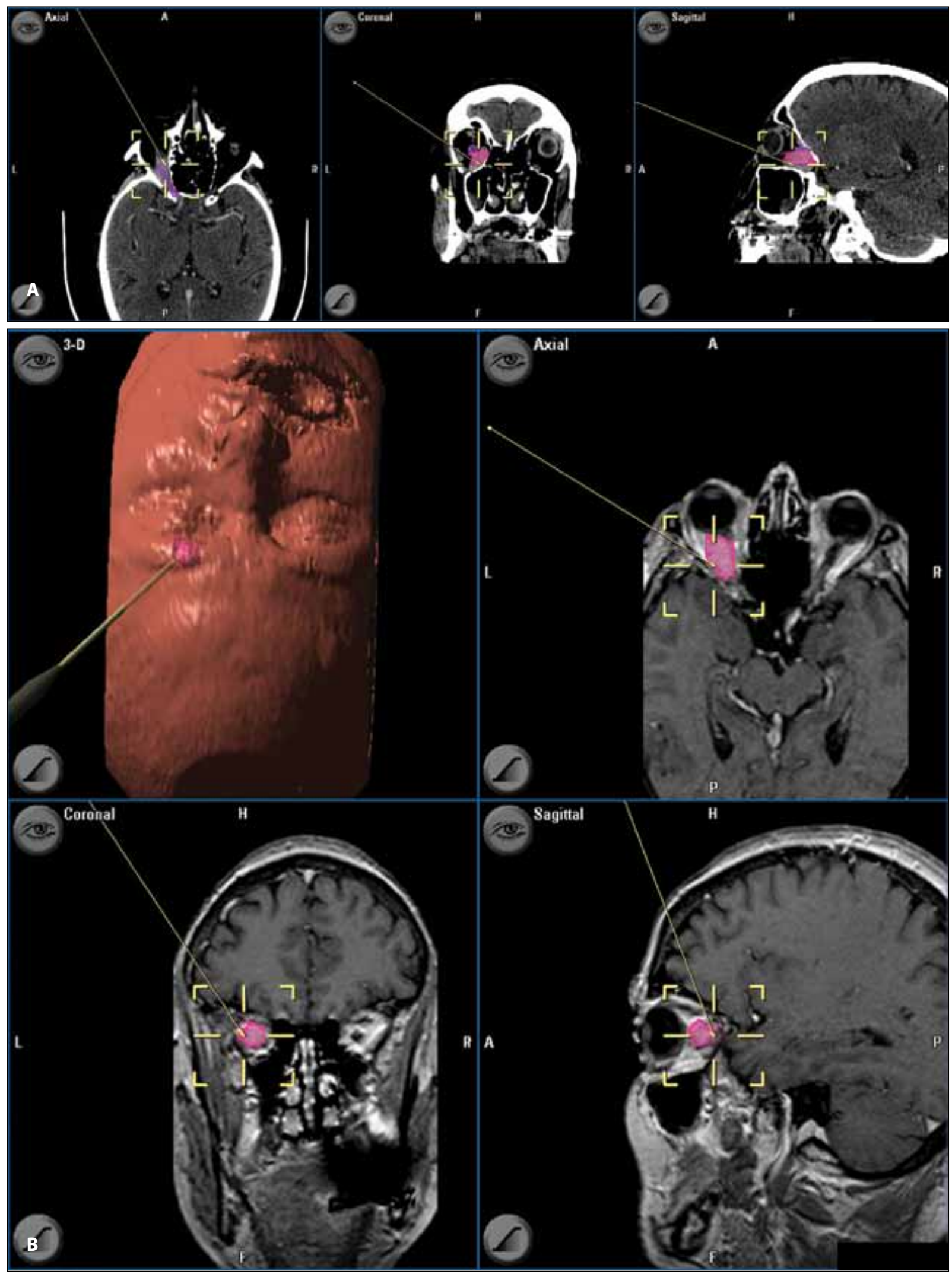

Figure 1: Intraoperative screenshots of neuronavigation-assisted resection of left orbital intraconal apical cavernomas (outlined in pink): A) Patient no. 3. CT-based neuronavigation. The optic nerve is outlined in purple. The lesion was totally removed by inferomedial orbitotomy. B) Patient no. 4. MRI-based neuronavigation. The lesion was totally removed by fronto-orbital craniotomy. 
most frequently (7 series), a magnetic one was used in 1 while the type of system for image guidance was not mentioned in 1 paper. The neuronavigation system worked properly during all of our procedures similar to the other series where none of the authors described any device-related technical problems or complications.

\section{Type of imaging modality used for neuronavigation}

Neuronavigated cranioorbital procedures, reported in the literature and including the interventions presented by the authors, were CT-based in 39 cases (3 authors' ones), MRIbased- in 5 cases ( 3 authors' ones) and based on image fusion between CT and MRI image sets in 15 patients (1 authors' one) (Table III). In 3 out of our 7 cases (two with intraconal apical tumours and one with an extraconal tumour), as in most of the aforementioned cases, the CT scans provided sufficient information for the image guidance of the procedure. An advantage of the CT-based image guidance was the excellent demonstration of the orbital bony walls and their relations to the tumours. A drawback of the CT-based neuronavigation was the poor visualization of the soft orbital tissues (9, 10). In another 3 of our cases (two with intraconal apical tumours and one with an extraconal tumour), out of totally 5 reported cases in the literature, the neuronavigation assisted procedure was MRI-based. The visualization of the orbital content was evaluated as excellent, but the bony structures were not well demonstrated $(9,10)$. The drawbacks of the CTbased and MRI-based neuronavigational procedures could be surmounted by an integration of both imaging sets and their simultaneous application $(9,10)$. In 1 of our cases, out of a total of 15 reported in the literature, the neuronavigation was based on image fusion between the $C T$ and MRI imaging sets. Neuronavigation based on CT and MRI fusion indisputably represents the most informative option for image guidance. Nevertheless its routine application is limited by the associated higher expenditure.

\section{Preoperative processing of image data sets for neuronavigation}

The duration of the preoperative processing for the image sets for our cranioorbital neuronavigational procedures differed in no way from the reported in the literature (10, 13). The preoperative simulation of the possible surgical approaches to the cranioorbital tumours in our series was extremely valuable for choosing the optimal approach in every particular case.

\section{Registration duration}

The registration process of the neuronavigation-assisted procedures in our series prolonged the overall operative time an average of 10 minutes, which is similar to that in published series $(2,11)$. The duration of the neuronavigational surgery, however, was reduced uniformly.

\section{Registration accuracy}

The registration accuracy is not mentioned in most of the discussed papers. It is only present in the Hejazi (11) neurosurgical study and the present authors' series. We reported an average accuracy of $1.3 \mathrm{~mm}$, which is better than the $1.9 \mathrm{~mm}$ achieved by Hejazi (11).

\section{Intraoperative accuracy}

We checked the intraoperative neuronavigation accuracy in our series by pointing at typical anatomical bony landmarks and estimated the result quality as consistently high. However, the intraoperative accuracy of the neuronavigation-assisted cranioorbital procedures was described in the literature only once, in the aforementioned study of Hejazi (11).

The inevitable protrusion of periorbital adipose in the course of orbital surgery tissue usually causes shift of the lesion and provokes a decrease in intraoperative accuracy. Thus, the reliability of intraoperative neuronavigation theoretically diminishes with time, as in the case with any other

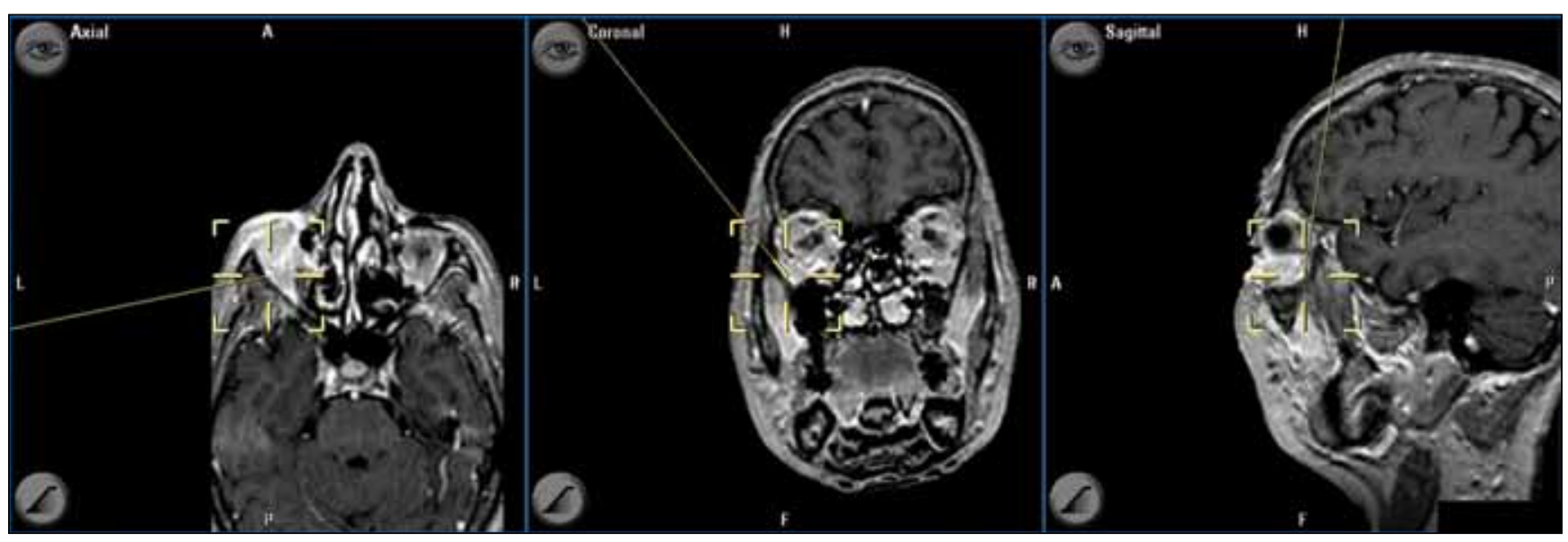

Figure 2: Intraoperative screenshot of neuronavigation-assisted resection of orbital sarcoid granuloma: Patient with left extraconal inferior sarcoid granuloma (patient no. 1). MRI-based neuronavigation. The granuloma was partially resected by lateral orbitotomy. 


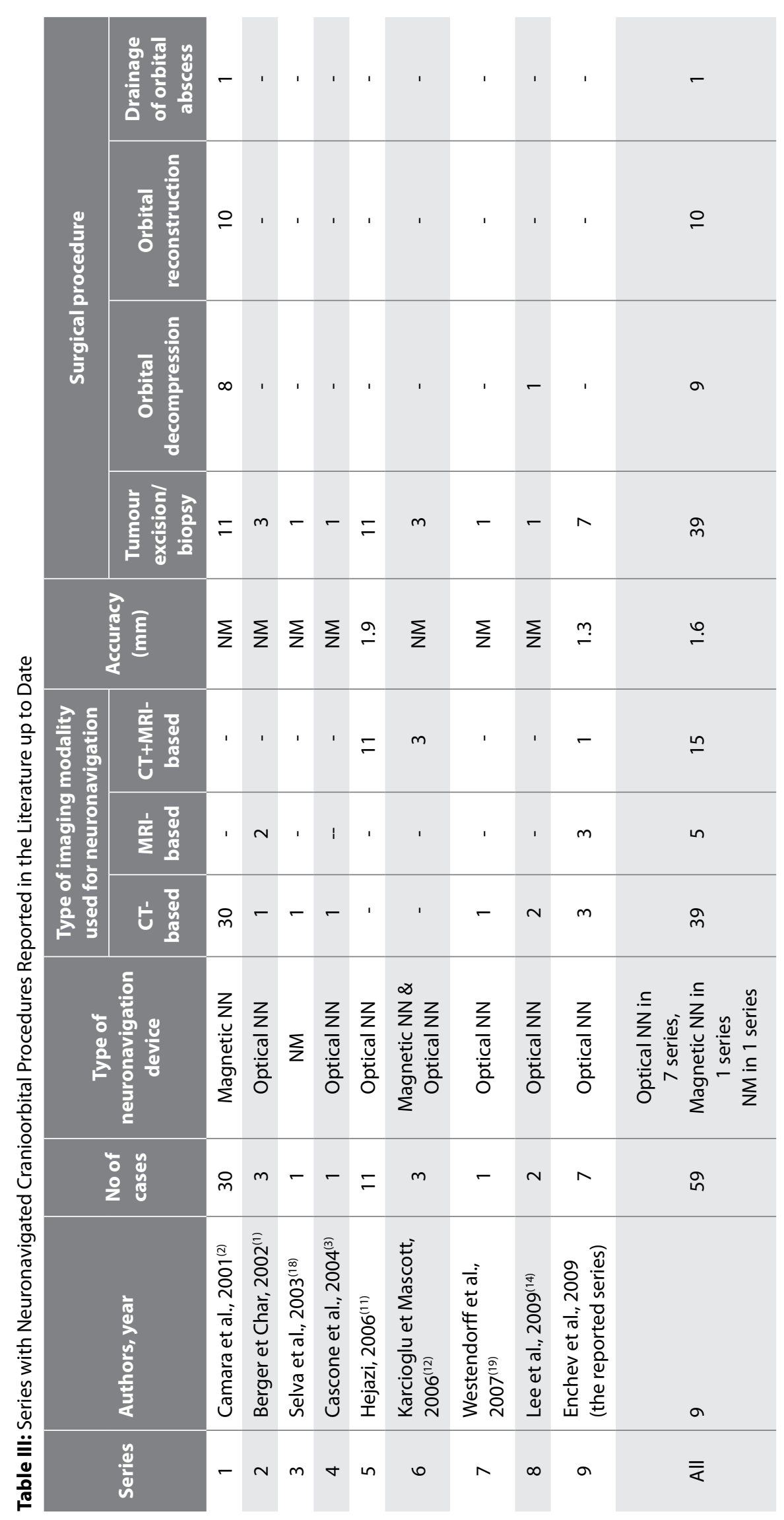

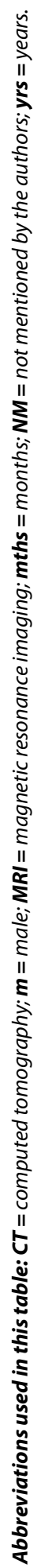




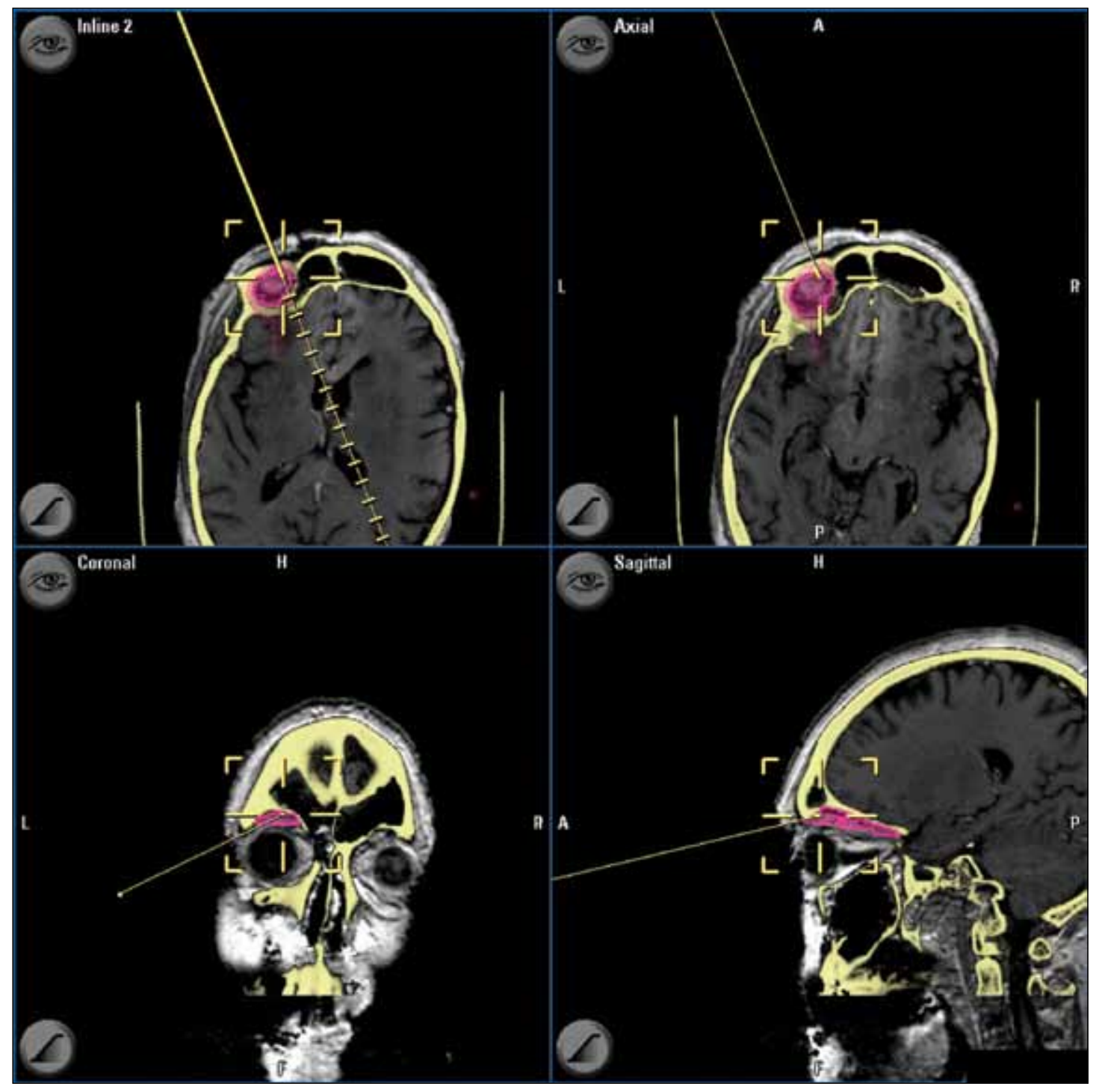

Figure 3: Intraoperative screenshot of neuronavigation-assisted resection of orbital abscess: Patient with left extraconal abscess engaging the neighbouring frontal sinus (patient no. 7). Neuronavigation based on CT and MRI fusion. The abscess is outlined in pink. The lesion was totally removed by trans-supraciliar approach.

neuronavigational procedure. However, a stage in which neuronavigation is significantly inaccurate is practically never reached in orbital pathologies due to the anatomical features of the orbit and its contents (see above). It must therefore be adopted as a rule that the neuronavigational surgical procedure must start with the most critical dissection, leaving the safer manipulations for the end.

\section{Surgical procedure}

The neuronavigation-assisted cranioorbital neurosurgical procedures reported in the literature comprise 39 cases of tumour excision or biopsy (including the 7 cases in the current series), 9 cases of orbital decompression, 10 cases of orbital reconstruction and 1 case of orbital abscess drainage (Table III). Neuronavigation was extremely useful for tumour localization, delineation of the tumour margins, evaluation of the extent of tumour resection and avoidance of important neurovascular structures in the cases with tumour excision or biopsy $(1-3,11,12,14,18)$. In the series with orbital decompression and orbital reconstruction, neuronavigation was used to verify the extent of decompressive bone removal, to prevent sudden dangerous cranial penetration and to verify the exact position of the applied grafts $(2,14,19)$.

Does Neuronavigation increase the grade of resection of cranioorbital tumours?

The authors of all the aforementioned series $(1-3,11,12,14$, $18,19)$ assert that neuronavigation increases the extent of tumour resection independently of the type of pathology or surgical approach. We also believe that the statement is 
true but unfortunately we do not have any unconditional evidences. The difficulty with the attempt to prove the point is associated with the common well-known ethical problemshow to refuse neuronavigation assistance to some patients if we are convinced of its advantages. The situation is very similar to the non-evidence-based introduction of the operative microscope in neurosurgery several decades ago. In this case we should accept indisputably the fact that neuronavigation is beneficial as it was accepted that the microscope is useful without any randomized studies. In both cases there were some arguments against the application of these devices, but again they were not-evidence-based.

Does Neuronavigation increase the grade of safety of cranioorbital surgeries?

We believe, similarly to the rest of the studies $(1-3,11,12$, $14,18,19)$, that neuronavigation in cranioorbital surgery increases the surgical safety and in this way reduces the intraoperative hazards for the patients.

\section{Future trends}

The integration of neuronavigation, with intraoperative MRI, CT or Ultrasound aiming real-time upgrading of the neuronavigational image data sets will be the definite solution for the existing, although not significant, brain shift phenomenon (10).

\section{Drawbacks of the current study}

The main disadvantage, of the current study and of all other studies concerning the application of neuronavigation in cranioorbital tumours, is the limited number of patients and the lack of a randomized control group. These problems, however, are similar to every other cranial application of neuronavigation.

\section{CONCLUSIONS}

The application of neuronavigation in cranioorbital surgery requires short learning curve. The neuronavigation assistance, based on image fusion between CT and MRI image data sets, undoubtedly is the most informative and useful image guidance for the surgeon. In the literature, in most of the series of neuronavigation assisted cranioorbital surgeries, the average accuracy of neuronavigation is not mentioned. The authors assert that in these cases neuronavigation increases the grade of resection of the cranioorbital tumours and the safety of surgery. Obviously, the conclusions of most of the authors are not objective and evidence based, but subjective and based on their personal impressions. Actually, randomized controlled trials also do not exist for the rest of the neuronavigational cranial applications. We believe that neuronavigation does not substitute the surgeon's knowledge, experience and his or her ability for virtual $3 \mathrm{D}$ reconstruction and $3 \mathrm{D}$ conception. However, we are convinced that neuronavigation should be an undivided part of any cranioorbital procedure.

\section{REFERENCES}

1. Berger $M$, Char $D H$ : Interactive image guidance for surgical localization of orbital apical tumors. Orbit 21:199-203, 2002

2. Camara JG, Nguyen LT, Fernandez-Suntay JP, Nardin GF, Sua SA: The use of a computer-assisted image-guided system (InstaTrak) in orbital surgery. Ophthal Plast Reconstr Surg 17: 447-451, 2001

3. Cascone $P$, Santamaria $S$, Mercurio A, Polito E: The use of neuronavigator in the orbital surgery of a rare case of RosaiDorfman disease. J Craniofac Surg 15: 651- 654, 2004

4. Enchev $Y$, Bozinov O, Miller D, Tirakotai W, Heinze S, Benes L, Bertalanffy $H$, Sure U: Image-guided ultrasonography for recurrent cystic gliomas. Acta Neurochir (Wien) 148(10): 1053-1063, 2006

5. Enchev Y, Oi S: Historical trends of neuroendoscopic surgical techniques in the treatment of hydrocephalus. Neurosurg Rev 31(3): 249-262, 2008

6. Enchev YP, Popov RV, Romansky KV, Marinov MB, Bussarsky VA: Role of neuronavigation in the resection of intracranial arteriovenous malformations. Folia Med (Plovdiv) 50(1):40-45, 2008

7. Enchev YP, Popov RV, Romansky KV, Marinov MB, Bussarsky VA: Cranial neuronavigation-a step forward or a step aside in modern neurosurgery. Folia Med (Plovdiv) 50(2): 5-10, 2008

8. Enchev YP, Popov RV, Romansky KV, Marinov MB, Bussarsky VA: Neuronavigated surgery of intracranial cavernomas--enthusiasm for high technologies or a gold standard? Folia Med (Plovdiv) 50(2): 11-17, 2008

9. Enchev YP, Popov RV, Romansky KV, Marinov MB, Bussarsky VA: Effect of the type of image study (CT or MRI) on some parameters of neuronavigation-assisted procedures. Folia Med (Plovdiv) 50(3): 47-52, 2008

10. Enchev Y: Neuronavigation: Geneology, reality and prospects. Neurosurg Focus 27(3): E11, 2009

11. Hejazi N: Frameless image-guided neuronavigation in orbital surgery: Practical applications. Neurosurg Rev 29: 118-122, 2006

12. Karcioglu ZA, Mascott CR: Computer-assisted image-guided orbit surgery. Eur J Ophthalmol 16: 446 -452, 2006

13. Kurtsoy A, Menku A, Tucer B, Koc RK, Oktem IS, Akdemir H: Computer-assisted stereotactic neuronavigation for intracranial mass lesions: Preliminary clinical experience in 63 cases. Turk Neurosurg 12: 33-38, 2002

14. Lee KYC, Ang BT, Ng I, Looi A: Stereotaxy for surgical navigation in orbital surgery. Ophthal Plast Reconstr Surg 25: 300-302, 2009

15. Lee SH, Koh JS, Bang JS, Kim GK: A case of ruptured peripheral aneurysm of the anterior inferior cerebellar artery associated with an arteriovenous malformation: A less invasive imageguided transcortical approach. J Korean Neurosurg Soc 46(6): 577-580, 2009

16. Oi S, Enchev Y: Neuroendoscopic foraminal plasty of foramen of Monro. Childs Nerv Syst 24(8): 933-942, 2008

17. Roberts DW, Strohbehn JW, Hatch JF, Murray W, Kettenberger H: A frameless stereotaxic integration of computerized tomographic imaging and the operating microscope. J Neurosurg 65: 545-549, 1986

18. Selva D, Chen C, Wormald PJ: Frontoethmoidal osteoma: A stereotactic - assisted sino-orbital approach. Ophthal Plast Reconstr Surg 19: 237- 238, 2003

19. Westendorff C, Kaminsky J, Ernemann U, Reinert S, Hoffmann $\mathrm{J}$ : Image-guided sphenoid wing meningioma resection and simultaneous computer- assisted cranio-orbital reconstruction: Technical case report. Neurosurgery 60(2 suppl 1): E173- E174, 2007 